\title{
URIHESIVE: A NEW AID IN THE MANAGEMENT OF URINARY INCONTINENCE IN MALE PARAPLEGIC PATIENTS
}

\author{
By J. de Leval, M.D. and J. C. Louis \\ Urological Clinic, Baviere Hospital, Liège, Belgium
}

Abstract. Our past practice with incontinent paraplegic patients has been to attach to the penis the sheath incorporated in urinary drainage devices by means of Elastoplast tape. Frequent development of skin lesions due to local irritation, and the necessity to wind Elastoplast tightly around the penis, which may produce urethral diverticula, has led us to use Urihesive to attach the sheath to the urinary drainage device.

Urihesive has been used continuously for several months in 18 paraplegic patients. It has proved to be highly superior to Elastoplast, for the following reasons:

It produces a better seal, resulting in no leakage of urine, and has better elasticity; it prevents the development of skin lesions and aids healing to existing lesions; there is no urethral constriction and the patient is more comfortable.

Key words: Paraplegia; Urinary incontinence.

\section{Introduction}

HITHERTO paraplegic patients under our care, with urinary incontinence difficulties, have been initially assisted by the insertion of a catheter as part of a re-training programme, followed either by percussion in cases with upper motor neurone involvement or by abdominal pressure when a lower motor neurone is implicated. Frequently, however, urinary incontinence is still a problem even after bladder equilibrium has been established to the extent of complete voiding without retention and the absence of infection. The urinary leakage varies in volume between patients and may either be continuous or intermittent, but it is always uncomfortable and embarrassing to the patient.

The plethora of devices on the market is an indication of the difficulties involved in constructing an efficient apparatus which would eradicate the problem of urinary incontinence. All of them, in one way or another, have proved themselves to be unsatisfactory in terms of efficiency.

We were pleased to have the opportunity to try out a new product, Urihesive, an adhesive material for attaching the contraceptive sheath of the urinary drainage device to the penis.

\section{Material and Methods}

Urihesive is an adhesive strip composed of gelatin, pectin, sodium carboxymethylcellulose and polyisobutylene. We used this product to attach the contraceptive sheath to the penis. Urihesive has a silicone release paper on both sides of the adhesive itself. The strips of Urihesive we used were $I \mathrm{~cm}$ wide and $10 \mathrm{~cm}$ in length. After removing the silicone paper from one side it was then placed around the penis proximal to the glans. The silicone paper was removed from the other side and the adhesive attached to the contraceptive sheath (Figs. I and 2). 


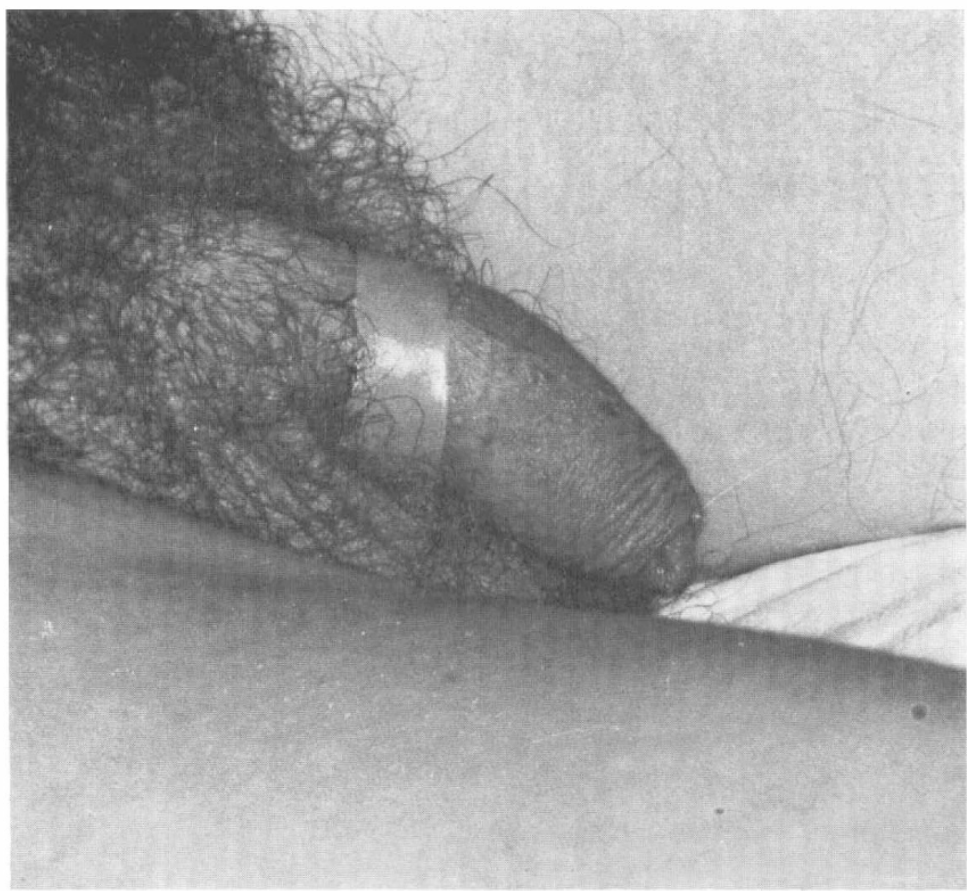

FIG. I

Urihesive placed around the penis.

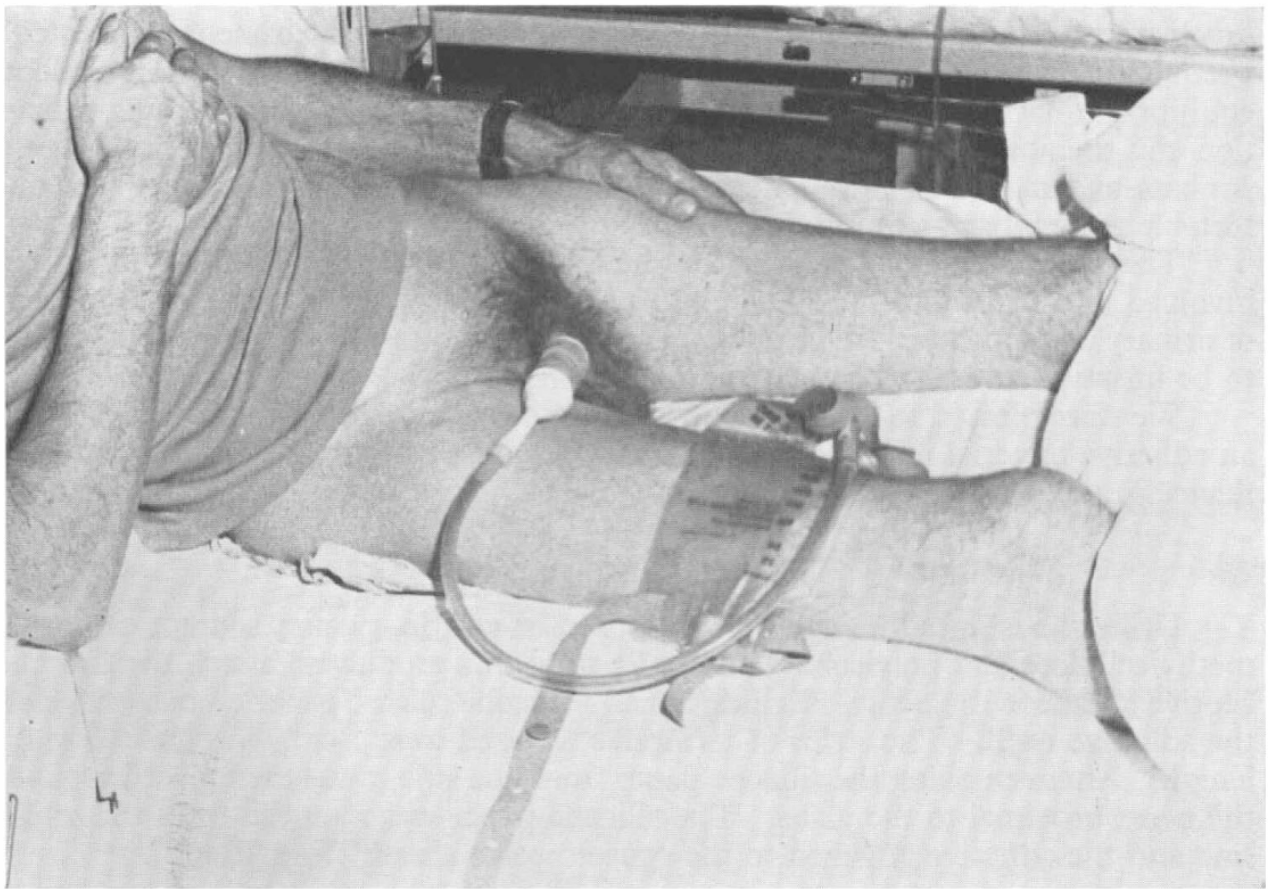

FIG. 2

Contraceptive sheath applied to Urihesive attached distally to the urine drainage device. 


\section{Results}

Eighteen paraplegic patients were involved in this trial, I I of whom have been so treated for over 3 months. Our results are summarised in Tables I and II.

\section{Discussion and Conclusions}

For many years we have used a contraceptive sheath, open at both ends, which is connected to a bag attached to the lower part of the leg, in an attempt to prevent undesirable leakage. This procedure has not always proved effective because of the difficulty of retaining the penis in an appropriate position. We have

TABLE I

\begin{tabular}{|c|c|c|c|c|c|c|c|}
\hline \multirow[t]{2}{*}{ Patients } & \multirow{2}{*}{$\begin{array}{l}\text { Duration } \\
\text { (months) }\end{array}$} & \multicolumn{2}{|c|}{ Prevention of leakage } & \multicolumn{2}{|c|}{ Patient acceptance } & \multicolumn{2}{|c|}{ Skin condition } \\
\hline & & Before & With & Before & With & Before & With \\
\hline I S. J. & 7 & + & ++ & + & ++ & erythema & $\mathrm{N}$ in 5 days \\
\hline 2 H. J. & 2 & ++ & ++ & + & ++ & ulceration & $\mathrm{N}$ in 15 days \\
\hline 3 R. E. & 7 & + & ++ & OR & ++ & $\begin{array}{l}\text { severe } \\
\text { ulceration }\end{array}$ & $\mathrm{N}$ in Io days \\
\hline 4 N. A. & 5 & + & ++ & $+\mathrm{R}$ & ++ & ulceration & $\mathrm{N}$ in Io days \\
\hline $5 \mathrm{~V} . \mathrm{J}$. & 3 & + & ++ & + & ++ & ulceration & $\mathrm{N}$ in 8 days \\
\hline 6 M. J. & 7 & $\mathrm{OE}$ & ++ & $\mathrm{OE}$ & ++ & erythema & $\mathrm{N}$ in 7 days \\
\hline $7 \mathrm{~K}$ & 2 & ++ & ++ & ++ & ++ & $\mathrm{N}$ & $\mathrm{N}$ \\
\hline 8 C. L. & 3 & + & ++ & + & ++ & $\mathrm{N}$ & $\mathrm{N}$ \\
\hline 9 P. J. & I & + & ++ & $+\mathrm{E}$ & ++ & $\mathrm{N}$ & $\mathrm{N}$ \\
\hline IO $\mathrm{A}$ & 5 & ++ & ++ & ++ & ++ & $\mathrm{N}$ & $\mathrm{N}$ \\
\hline II $\mathrm{P}$ & 2 & ++ & ++ & ++ & + & $\mathrm{N}$ & $\mathrm{N}$ \\
\hline I2 L & 0,5 & ++ & ++ & ++ & + & $\mathrm{N}$ & $\mathbf{N}$ \\
\hline I3 H. A. & I & $\begin{array}{l}\text { cathe- } \\
\text { terised }\end{array}$ & ++ & $\begin{array}{l}\text { cathe- } \\
\text { terised }\end{array}$ & ++ & $\mathrm{N}$ & $\mathrm{N}$ \\
\hline I4 DEB & 3 & $\begin{array}{l}\text { cathe- } \\
\text { terised }\end{array}$ & ++ & $\begin{array}{l}\text { cathe- } \\
\text { terised }\end{array}$ & ++ & $\mathrm{N}$ & $\mathrm{N}$ \\
\hline I5 Gust & 3 & $\mathrm{O}$ & + & $\mathrm{O}$ & + & erythema & $\mathrm{N}$ in 8 days \\
\hline $16 \mathrm{~S}$ & I & ++ & ++ & ++ & ++ & erythema & $\mathrm{N}$ in 7 days \\
\hline I7 $\mathrm{BCH}$ & 3 & $\begin{array}{l}\text { cathe- } \\
\text { terised }\end{array}$ & ++ & $\begin{array}{l}\text { cathe- } \\
\text { terised }\end{array}$ & ++ & $\mathrm{N}$ & $\mathbf{N}$ \\
\hline I8 B & I & + & ++ & + & ++ & $\mathrm{N}$ & $\mathrm{N}$ \\
\hline
\end{tabular}

$\mathrm{O}=$ bad + = good $++=$ excellent. $\quad \mathrm{E}=$ erection; $\mathrm{R}=$ retraction; $\mathrm{N}=$ normal.

TABLE II

\begin{tabular}{lcccccc}
\hline & $\begin{array}{c}\text { Prevention of leakage } \\
\text { Before }\end{array}$ & $\begin{array}{c}\text { Patient acceptance } \\
\text { With }\end{array}$ & $\begin{array}{c}\text { Skin condition } \\
\text { Before }\end{array}$ & With & \multicolumn{2}{c}{$\begin{array}{c}\text { Before } \\
\text { With }\end{array}$} \\
\hline Excellent & 6 & I8 & 5 & I & I0 & I8 \\
Good & 7 & & 7 & 3 & 8 & \\
Bad & 2 & & 3 & & \\
Catheterised & 3 & & 3 & & \\
\hline
\end{tabular}


attempted to overcome this by strapping the proximal part of the penis to the contraceptive sheath by the use of Elastoplast. This technique also gave rise to problems because of the difficulty of placing the Elastoplast in the precise position required to prevent leakage. We found that successive removal and replacement of the Elastoplast produced traumatic skin disorders on the penis. Such lesions occurred in 30 per cent of our patients. On some occasions we had to wind the Elastoplast tightly two or three times around the penis to achieve our objective. Other patients developed diverticula of the urethra, fistulae and one case was readmitted because of acute urinary retention.

It is apparent that our technique was not entirely satisfactory because it did not comply with the criteria for an efficient device, which are that (a) it should be easy for the patient to apply, (b) it should prevent leakage, (c) it should not reduce urine flow due to pressure on the urethra, (d) it should not give rise to traumatic or reactive skin reactions and (e) it should not be expensive.

From our results, we have come to the conclusion that Urihesive represents a significant advance over the use of Elastoplast, for the following reasons:

(a) Its adhesive properties are superior to Elastoplast. We found that Urihesive remained in situ for I to 3 days.

(b) It can be applied irrespective of the skin condition.

(c) It completely prevents leakage.

(d) It does not restrict urinary flow.

(e) Patient acceptance is excellent.

(f) Its elasticity allows it to adapt to changes in the diameter of the penis.

(g) It does not interfere with rapid healing of skin lesions which would previously have been exacerbated by Elastoplast.

\section{RÉSUMÉ}

Pour résoudre les problèmes d'incontinence résiduelle des patients paraplégiques rééduqués, nous utilisions un étui pénien fixé par du sparadrap. La fréquence des lésions cutanées, l'obligation de serrer le sparadrap autour de la verge et l'apparition de diverticules uréthraux nous ont incité à utiliser le Urihesive pour fixer l'étui pénien. Dix-huit paraplégiques appareillés pendant plusieurs mois avec le Urihesive ont confirmé sa supériorité au point de vue étanchéité, élasticité, prévention et guérison des lésions cutanées, absence de constriction uréthrale et confort du patient.

\section{ZUSAMMENFASSUNG}

Urihesive, eine neue Methode in der Behandlung von Urininkontinenz wurde an I8 Paraplegikern für mehrere Monate angewandt. Es erwies sich vielfach superior im Vergleich mit Elastoplast; es hat eine bessere Elastizität und folglich eine bessere Abdichtung, weiterhin es verhindert Hautläsionen und beschleunigt die Heilung bestehender Läsionen. Es verursacht keine urethrale Konstriktion und der Patient fühlt sich angenehmer.

Acknowledgements. We are grateful to E. R. Squibb \& Sons for placing supplies of Urihesive at our disposal and we acknowledge the assistance given to us by Mr R. Galasse, Medical Affairs Manager of the Company. 